\title{
POSITIVO/NEGATIVO: DOS EFEITOS DE SENTIDO E IMAGINÁRIO SOBRE HIV NA CAMPANHA DISCRIMINAÇÃO ZERO
}

\author{
EZEQUIEL NUNES PIRES ${ }^{1}$
}

\author{
Instituto de Letras - Programa de Pós-graduação em Letras \\ Universidade Federal do Rio Grande do Sul \\ Av. Bento Gonçalves, 9500 - 91501-970 - Porto Alegre - RS
}

nuneseze@gmail.com

\begin{abstract}
Resumo. O seguinte trabalho pretende explorar os processos discursivos na campanha sobre HIV/AIDS intitulada Discriminação zero, principalmente através dos pensamentos de Pêcheux (2007, 2014, 2015) e Trevisan (2018). Levando em conta efeitos de sentido de determinada formação discursiva evocados em relação à doença e ao vírus, busca-se compreender os funcionamentos das condições de produção desses discursos. Para além dos objetivos da campanha, como prevenção e tratamento, também, busca-se pela diminuição de preconceitos e estigmatização da doença que se apresenta, muitas vezes, em um imaginário que memora a morte. A campanha apresenta-nos diferentes discursos de diferentes formações discursivas em que a palavra positivo pode desencadear diferentes sentidos.
\end{abstract}

Palavras-chave: Análise do discurso; HIV/AIDS; Efeitos de sentido; Publicidade institucional; Saúde pública.

\begin{abstract}
The present work aims to explore the discursive processes in the advertisement about HIV/AIDS entitled Zero discrimination, mainly with the thoughts of Pêcheux (2007, 2014, 2015) and Trevisan (2018). Taking into account the imaginary evoked in relation to the disease, we seek to understand the functioning of the conditions of speech production present in the campaign. Thinking that in addition to campaign objectives, such as prevention and treatment, is also present the search for the reduction of prejudice and stigmatization of the disease that often presents itself in an imaginary that evokes death. The campaign presents us with different discourses from different discursive formations in which the word positive may contain different meanings.
\end{abstract}

Keywords: Discourse analysis; HIV/AIDS; Meaning effects; Institutional advertising; Public health.

\footnotetext{
${ }^{1}$ Licenciado em Letras Português/Inglês pelo Instituto Federal do Rio Grande do Sul (IFRS), mestrando em Letras na Universidade Federal do Rio Grande do Sul (UFRGS) na linha de Análises textuais, discursivas e enunciativas e bolsista CAPES.
} 
No terreno da linguagem, a luta de classes ideológica é uma luta pelo sentido das palavras, expressões e enunciados. (PÊCHEUX, 2015a, p. 273).

\section{INTRODUÇÃO}

Esperava o ônibus um dia quando observei um cartaz na traseira de outro ônibus (busdoor) que passava. Li de longe "abraçar é positivo", mas as letras miúdas no restante do anúncio já não se enxergavam, o "t" na palavra positivo se apresentava diferente das outras letras, era, na verdade, o sinal de positivo (+) na cor vermelha. No primeiro momento, não soube dizer ao que se referia o enunciado, mas o estranhamento que foi causado decorreu daquele sinal no lugar da letra. Mais tarde descobrira que o cartaz pertencia a uma campanha sobre o Vírus da Imunodeficiência Humana (HIV) e a Síndrome da imunodeficiência adquirida (SIDA; em inglês: Acquired Immunodeficiency Syndrome, AIDS).

O primeiro caso da doença (AIDS) identificado no Brasil ocorreu no ano de 1982, sendo que, segundo redação da revista Superinteressante (2018), a doença "que pode ter aparecido nos anos 30, só foi identificada em 1981". Isso demonstra o quanto o vírus se espalhou pelo mundo, acarretando, na época, em diversas mortes em decorrência da AIDS por não haver tratamento e nem cura. Hoje, em relatórios do UNAIDS (Programa Conjunto das Nações Unidas sobre HIV/AIDS), é possível perceber que mesmo que haja muitas pessoas no mundo vivendo com HIV (cerca de 37,9 milhões de soropositivos), o número de novas infecções e mortes pela doença não cresceram em comparação com o passado, "a mortalidade relacionada à AIDS diminuiu 33\% desde 2010" e "novas infecções por HIV foram reduzidas em 40\% desde o pico em 1997", apontam as estatísticas do UNAIDS (2018).

Esses resultados se dão em conta dos tratamentos à base de antirretrovirais. Esses medicamentos agem inibindo a multiplicação do vírus no organismo e controlando a sua reprodução se pode chegar a uma baixa carga viral ou zero (o que impede a transmissão). No Brasil, segundo o Ministério da Saúde, desde 1996 são distribuídos "gratuitamente pelo SUS (Sistema Único de Saúde) todos os medicamentos antirretrovirais e, desde 2013, o SUS garante tratamento para todas as pessoas vivendo com HIV (PVHIV), independentemente da carga viral.".

Entende-se que o HIV é o responsável causador da AIDS quando não só há uma alta carga viral no organismo do ser humano como baixo nível de células CD4 no sangue, uma das responsáveis por garantir a defesa do organismo mantendo o corpo livre de doenças. $\mathrm{O}$ vírus ataca o sistema imunológico e nisso interfere o organismo no combate de infecções, causando diversas complicações ao paciente (até mesmo a morte). Compreende-se que as únicas formas de transmissão do vírus se dão por contato sexual sem proteção, contato sanguíneo (transfusão, uso de seringa por mais de uma pessoa e instrumentos que furam/cortam não esterilizados) e materno (transmitindo para o/a filho/a durante gravidez, parto e amamentação) e sabe-se que uma pessoa soropositiva em terapia antirretroviral com carga viral zerada não transmite o vírus. Assim, damos continuidade a este trabalho. 
Nesse sentido, será evitado usar a dicotomia HIV/AIDS pelo fato de as duas coisas serem diferentes, pois ser portador do HIV não significa, necessariamente, ser acometido também por AIDS, e será utilizada a sigla em inglês devido ao amplo reconhecimento. Em diversos momentos da história do HIV e da AIDS em nossa sociedade, a culpa das transmissões do vírus e da doença existir esteve atribuída aos homens homossexuais. Sobre o fator de vulnerabilidade, o site federal do departamento de DST, AIDS e Hepatites virais (2010) apontava que "o resultado positivo para o HIV está relacionado, principalmente, ao número de parcerias [...], à coinfecção com outras doenças sexualmente transmissíveis e às relações homossexuais." (grifo meu).

Colocar em evidência (até mesmo em uma plataforma federal) a homossexualidade como fator vulnerável para a transmissão do HIV estigmatiza a doença, cria e perpetua preconceitos de sexo e corrobora para aumento da homofobia. Como nos diz Trevisan:

\begin{abstract}
Apesar das alarmantes estatísticas confirmando a disseminação da aids nos mais diversos grupos sociais, o imaginário popular relacionava essa doença (antiga "peste guei") à prática sexual entre homens e ao gueto homossexual, onde ela se desenvolveu, no eixo Europa/América do Norte/América Latina. Por isso, a aids era sentida como reveladora e, com isso, estigmatizante. (TREVISAN, 2018, p. 40).
\end{abstract}

Nesse sentido, como aponta o autor, ser portador do HIV ou/e ser acometido por AIDS era uma confirmação de sua homossexualidade. Isso se torna grave a partir do fato de que vivemos em uma sociedade falocêntrica, em que a virilidade do homem "macho" é supervalorizada e a heterossexualidade como padrão é socialmente aceita, desse modo, sempre empurrando as minorias sexuais, no caso os homossexuais, à margem da sociedade, vítimas de discriminação, violências e violações.

Nos primeiros anos do descobrimento da AIDS e do HIV, então, foi popularizado que os responsáveis eram os homens homossexuais. Contribuindo para tal imaginário ser criado e popularizado, a imprensa teve um forte papel enquanto publicava manchetes com tais enunciados: "Peste-gay já apavora São Paulo"2; "Peste gay é a epidemia do século"3; "Aids é castigo de Deus, porque bicha é uma raça desgraçada"4,"Câncer gay: grupo de São Paulo lança alerta"5.

Esses enunciados reforçam o que antes foi discutido. Criou-se um estigma para a AIDS, a qual se apresentava como uma doença somente de gays, contribuindo para a crescente do preconceito, aversão e discriminação contra essa minoria sexual. Talvez, um efeito de sentido possível para tais dizeres, é que seria pior ser homossexual do que contrair o HIV, tendo em vista os discursos que culpam os homossexuais pela doença e únicos acometidos, notabilizando a homofobia acima da fobia da doença. Sendo assim, nos anos que se seguem, a doença se apresenta como um tabu, uma vergonha, é quase que

\footnotetext{
2 Jornal Notícias Populares, 1983.

3 Jornal da década de 80, disponível em: http://4.bp.blogspot.com/ASA9L7kEMu0/TWfmmKhS59I/AAAAAAAAAGs/NqzjX0a_xHY/s200/peste-gay.jpg.

4 Jornal da década de 80, disponível em: https://ogimg.infoglobo.com.br/in/23264427-c82-

9f7/FT1086A/652/xaids.jpg.pagespeed.ic.v5lzQ4Jkwk.jpg.

${ }^{5}$ Jornal O País, 1983.
} 
proibido contar sobre a soropositividade, arriscando rechaços sociais dos diferentes tipos. Hoje, a luta contra a AIDS e HIV continua, enquanto se busca conscientizar a população sobre formas de contágio e proteção, também é objetivo diminuir os estigmas, lutar contra preconceitos e mostrar que o toque, o carinho e o amor são posi+ivos.

\section{A CAMPANHA: UM CORPUS DISCURSIVO}

Em abril de 2019 foi lançada, pelo Observatório de HIV/AIDS do Estado do Rio Grande do Sul, a campanha ${ }^{6}$ Zero discriminação, com apoio da Secretaria de Saúde do Estado e do Ministério da Saúde. Deste modo, neste trabalho serão analisados os discursos que a campanha carrega, com o objetivo de compreender os diferentes efeitos de sentido que ali se apresentam e o imaginário sobre esses discursos.

O objetivo da campanha é demonstrar que diversas ações do nosso dia a dia que envolvem contato humano não são fatores de risco de transmissão do vírus causador da AIDS. Sendo assim, em comparação com os primeiros discursos sobre o HIV e AIDS no Brasil (as manchetes de jornais da década de 80), pensemos o trabalho que novas campanhas como essa tentam desenvolver.

No próprio site do Observatório, a campanha se apresenta de diferentes formas. Primeiro, há um vídeo de 1 minuto e 55 segundos que mostra o convite realizado a dez pessoas para realizarem tarefas simples entre si, o detalhe é que uma delas é HIV+ (soropositivo). Entre essas tarefas estão um aperto de mãos, um beijo no rosto, compartilhar o mesmo chimarrão em uma roda de conversa e um abraço em duplas. Então aparecem os dizeres: "resultado: no final do experimento, nada mudou. Uma delas é HIV positivo" (grifos do autor), "abraçar é posi+ivo, beijar é posi+tivo, tocar é posi+tivo, conversar é posi+tivo", "HIV posi+tivo" e "negativo é discriminar".

Há, também, uma versão do vídeo resumida. São 30 segundos de duração em que as ações aparecem com menos tempo e os dizeres no vídeo simultaneamente. Logo, quando acabam as ações, aparecem os dois últimos dizeres antes citados. Além dos vídeos

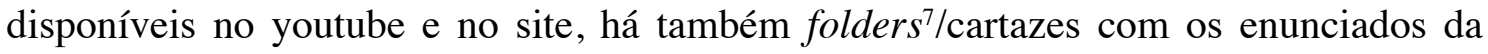
campanha. Foi um cartaz como esse, a seguir, que pude ver colado no vidro atrás do ônibus na cidade de Porto Alegre/RS.

\footnotetext{
${ }^{6}$ Termo utilizado conforme é apresentado no site http://observatorioaids.saude.rs.gov.br

7 Toda a campanha e matérias estão disponíveis em: http://observatorioaids.saude.rs.gov.br/?page_id=739.
} 


\section{HIV+. NEGATIVO É DISCRIMINAR. \\ Imagem 1: cartaz da campanha Discriminação zero. Fonte: http://observatorioaids.saude.rs.gov.br/?page_id=739 Acessado em janeiro de 2020.}

Desse modo, os enunciados apresentados da campanha constituem o corpus empírico de análise. Ou seja, entendendo língua como materialidade do discurso, e discurso como materialidade da ideologia, os discursos da campanha apresentados enquanto sequências discursivas formam o corpus discursivo que será aqui trabalhado, analisado. Mas antes das análises, trazemos as reflexões teóricas que nortearam este estudo.

\section{DISPOSITIVO TEÓRICO-ANALÍTICO}

A partir de três regiões do conhecimento (linguística, materialismo histórico e psicanálise), a Análise do Discurso Francesa, doravante AD, surge como uma disciplina que tomando o discurso como objeto a ser trabalhado se preocupa, acima de tudo, com as condições de produção de efeitos de sentido, ou seja, com o possível sentido (um efeito) que o processo discursivo pode apresentar.

Desse modo, "a Análise de Discurso concebe a linguagem como mediação necessária entre homem e a realidade natural e social." (ORLANDI, 2015, p. 13). A AD contribui para a compreensão dos sentidos que a língua produz, mais do que isso, a possibilidade de o sujeito significar e significar-se, o discurso funcionando como mediação da permanência ou transformação sócio-histórica e pessoal dos sujeitos. É nessa transformação que os três eixos de conhecimento da AD se encontram.

É no discurso que se pode observar a relação da língua com a ideologia, surgindo a compreensão de como a língua produz sentidos para e pelos sujeitos. Assim, Pêcheux \& Fuchs (2014b) determinam a noção de discurso:

Se deve conceber o discursivo como um dos aspectos materiais do que chamamos de materialidade ideológica. Dito de outro modo, a espécie discursiva pertence, assim pensamos, ao gênero ideológico, o que é o mesmo que dizer que as formações ideológicas de que acabamos de falar "comportam necessariamente, como um de seus componentes, uma ou várias formações discursivas interligadas que determinam o que pode e deve ser dito [...], a partir de uma posição dada numa conjuntura", isto é, numa certa relação de lugares no interior de um 
aparelho ideológico, e inscrita numa relação de classes. (PÊCHEUX \& FUCHS, 2014b [1975], p. 163-4).

Assim, para os autores, o discurso pertence ao gênero ideológico, ou seja, o sujeito apresenta sempre um discurso ideológico. O discurso advém de uma formação ideológica (FI), sendo essa composta por formações discursivas (FD) (conceito determinado no excerto acima grifado) interligadas que determinarão posições-sujeito que os indivíduos podem estar inscritos. "A ideologia interpela os indivíduos em sujeitos" (PÊCHEUX \& FUCHS, 2014b, p. 164). Dessa maneira, segundo os autores, os indivíduos são interpelados em sujeitos de seu discurso pelas formações discursivas que representam na linguagem as formações ideológicas que lhes são correspondentes. Dito de outra forma, a interpelação se dá pela identificação (do sujeito) com a formação discursiva que o domina, a partir do momento em que toma lugar (é inscrito) em uma posição-sujeito.

A posição-sujeito pode se apresentar de várias formas que se identificam mais ou menos com a forma-sujeito, uma noção que se faz presente como integradora da FD que, por sua vez, constitui a formação ideológica. A ideologia, juntamente com o sujeito, organiza a FD, que pode ser entendida, segundo Indursky, como o que pode e deve ser dito pelo sujeito e que tem os saberes regulados pela forma-sujeito. Desse modo, Pêcheux apresenta o funcionamento do que chama de "tomada de posição":

a tomada de posição resulta de um retorno do "Sujeito" no sujeito, de modo que a não-coincidência subjetiva que caracteriza a dualidade sujeito/objeto, pela qual o sujeito se separa daquilo de que ele 'toma consciência' e a propósito do que ele toma posição, é fundamentalmente homogênea à coincidência-reconhecimento pela qual o sujeito se identifica consigo mesmo, com seus 'semelhantes' e com o 'Sujeito'. O 'desdobramento' do sujeito - como 'tomada de consciência"' de seus objetos - é uma reduplicação da identificação [...]. (PÊCHEUX, 2014a, p. 160).

Indursky (2007) retoma, de Pêcheux, as modalidades de posição para repensá-las enquanto constituintes da FD heterogênea. Assim, três são as modalidades apresentadas: a primeira modalidade é a chamada de superposição, em que o sujeito do discurso é reconhecido como bom sujeito, pois se identifica plenamente com a posição-sujeito inscrita nos dizeres da formação discursiva. Essa modalidade é a reconhecida como reduplicação da identificação. Essa reduplicação acontece pois o sujeito reduplica os dizeres da FD em sua forma-sujeito na posição em que se inscreve.

A segunda modalidade irá apresentar-se como mau sujeito. O discurso desse sujeito se contrapõe à forma-sujeito, fazendo com que ele se contra-identifique com os dizeres da formação discursiva que o afeta. "A contra-identificação é um trabalho do sujeito do discurso sobre os dizeres e os sentidos que são próprios à FD que o determina e, por conseguinte, se institui como forma de resistência à forma-sujeito e ao domínio de saberes que ela organiza" (INDURSKY, 2007, p. 167).

É pelo fato de a identificação não ser completa que se abre espaço para as contradições, para a dúvida. Será com esta modalidade que a FD se tornará heterogênea, pois trará para o seu interior a alteridade, o discurso-outro. É o interdiscurso, o já-dito, 
que determina uma FD, pois contém os dizeres que não devem e devem ser ditos no âmbito dela.

Por sua vez, é apresentada a terceira modalidade, a de desidentificação. "O sujeito do discurso desidentifica-se de uma formação discursiva e sua forma-sujeito para deslocar sua identificação para outra formação discursiva e sua respectiva forma-sujeito" (INDURSKY, 2007, p. 168).

Quando se diz que os interlocutores são sujeitos historicamente determinados, significa dizer que são interpelados pela ideologia. E é deste modo que as condições de produção do discurso relacionam esse texto com os sujeitos históricos, identificados com uma formação discursiva e inscritos em lugares sociais. Tem-se, desse modo, "um sujeito descentrado que age sob a ilusão de estar na origem de seu dizer, mas que, precisa imergir no interdiscurso para poder dizer, pois aí reside o repetível, a memória discursiva que lhe permite dizer" (INDURSKY, 2010, p. 69).

São essas noções, dos processos de identificação do sujeito, que vão contribuir para a constituição das condições em que o discurso se produz e também para o seu processo de significação. Não é no dizer em si mesmo, nem pelas intenções de quem diz que se compreende o sentido. É preciso referir o dizer às suas condições de produção, estabelecer as relações que ele mantém com sua memória e também remetê-lo a uma formação discursiva. A memória possibilita que aconteça a produção de sentidos.

Pêcheux (2007, p. 50) define que "A memória discursiva seria aquilo que, face a um texto que surge como acontecimento a ler, vem restabelecer os "implícitos' [...] de que sua leitura necessita: a condição do legível em relação ao próprio legível" (PÊCHEUX, 2007, p. 52). Dito de outra forma, a memória é esse espaço não homogêneo de muitos dizeres (sócio-históricos), do já-dito, em contraste com o não-dito.

Nessa relação do que está sendo dito e o já-dito, traduz-se a relação entre o intradiscurso (formulação do sentido) e o interdiscurso (constituição do sentido). O interdiscurso é o eixo em que teríamos todos os dizeres já-ditos (o dizível); no outro eixo, o intradiscurso, é aquilo que estamos dizendo naquele momento dado, em condições dadas, as materialidades discursivas do enunciado. Como consequência disso, o dizer não é propriedade particular. As palavras não são só nossas. Elas significam pela história e pela língua. Observando o interdiscurso é possível remeter o dizer a uma filiação de dizeres, a uma memória, e a identificá-lo em sua historicidade e seus sentidos.

Segundo Orlandi (2015, p. 29), o interdiscurso disponibiliza dizeres que afetam o modo como o sujeito significa em uma situação discursiva dada. Nesse sentido, as condições de produção de um discurso podem ser consideradas em um sentido amplo em que instituições sociais e históricas significam segundo um imaginário que afeta os sujeitos. Configurando-se em memória, esse imaginário que nos afeta é constituído de uma rede de saberes e de dizeres.

Desse modo, tentemos definir as formações discursivas com as quais trabalharemos nas análises em seguida. Advindas dessa formação ideológica que é a da saúde, em que se apresentam os discursos, principalmente, que estão em relação ao bemestar da pessoa, teremos pelo menos duas formações discursivas que se pretendem 
opostas: a da discriminação e a da inclusão. Na primeira, se encontram os dizeres oriundos de um imaginário em que o diagnóstico para HIV+ é decreto de tempo de vida, certeza da morte, que conviver com o vírus pode ser contagioso. Já na formação discursiva da inclusão, os discursos buscam o combate ao preconceito, mostram que viver e conviver com o HIV não é sinônimo de morte. Nos discursos dessa formação discursiva, a característica é, justamente, o contrário dos estereótipos e estigmatizações impostos pela FD oposta - aquela que evoca um imaginário negativo sobre a pessoa que vive com HIV e a AIDS.

\section{A PALAVRA, O SINAL E A COR}

Tendo, então, como recorte discursivo os enunciados da campanha, é possível elencar algumas sequências discursivas que serão analisadas. Todo esse recorte se caracteriza principalmente pela matriz parafrástica que cria, sendo parte as seguintes sequências discursivas (SDs) que estão numeradas de acordo com a ordem em que aparecem na campanha, mais especificamente, no vídeo (em negrito os dizeres que na própria campanha aparecem destacados):

SD1: Abraçar é posi+ivo.

SD2: Beijar é posi+ivo.

SD3: Tocar é posi+ivo.

SD4: Conversar é posi+ivo.

SD5: Compartilhar é posi+ivo.

SD6: HIV posi+ivo.

SD7: Negativo é discriminar.

SD8: No final do experimento, nada mudou. Uma delas é HIV positivo.

Da sequência discursiva 1 a 6 tem-se o mesmo adjetivo para determinar os termos anteriores, seja com verbo de ligação ou não. Dito de outra forma, as simples ações do dia a dia, como abraçar, beijar, tocar, conversar e compartilhar se apresentam nessas materialidades linguísticas enquanto verbo, sendo necessário, para dar característica, qualidade às ações, o verbo de ligação ser. As SDs de 1 a 5 podem ser analisadas como um bloco, com uma mesma fórmula: verbo infinitivo (sujeito e objeto lacunares, o preenchimento se dá pela imagem ou pelo leitor) + é posi+ivo. Assim, a qualidade em comum entre as ações é a de serem positivas, o que ocorre diferente na SD6, que possui a mesma palavra como qualidade, porém qualificando o vírus (um substantivo). Desse modo, pode-se perceber que em uma matriz parafrástica, o vírus poderia possuir o sentido de mais uma ação diária, assim como essas ações poderiam adquirir o sentido de virais, ou seja, se espalharem, contagiarem. 
Assim, essas sequências discursivas se encontram nos ditos da formação discursiva da inclusão, de uma não discriminação. Elas apontam, nesse caso, para uma naturalização do HIV enquanto ações simples do cotidiano; o vírus, ordinariamente, não desqualifica alguém por ser seu portador, também, não identificado como algo ruim, negativo, motivo de preconceitos e exclusão.

Ainda, cabe pensarmos sobre os sentidos da palavra positivo. Do latim positivus, "determinado por acordo arbitrário", de positus, particípio passado de ponere, que significa "pôr", ou seja, positivo pode significar que há, pois tem sido posto, do contrário de não haver algo. Positivo também é um sinal usado em matemática, é um tipo de carga elétrica e aquilo/aquele centrado no que é bom. Sendo assim, as ações diárias sendo positivas com um verbo de ligação, podem significar que são boas ações. Diferente do vírus, que sendo positivo, significa que ele está no organismo (identificável ou não, intransmissível ou não). O objetivo, então, poderia ser pensar o vírus como algo que deixa de ser um fator negativo naqueles que o possuem, buscando apagar ou modificar um imaginário de que HIV significa morte, (sem) tempo e/ou qualidade de vida etc.

Nesse mesmo sentido, Trevisan escreve em seu texto referindo-se ao vírus como amigo, porque "todos trememos de medo ante o vírus da AIDS. É natural: todos tememos a morte que ele prenuncia. As reações são de pavor e até pânico. Às vezes, há reticências, e então não se ousa sequer mencionar essas terríveis quatro letrinhas" (TREVISAN, 2018, p. 616). Diversos são os casos de isolamento quando alguém se revela soropositivo, ou se isola ou é isolado. Uma reação compreensível, como aponta o autor, pois revela-nos o medo natural da morte. Desse modo, o autor aponta a desilusão de uma vida perfeita e a certeza da morte como algo positivo, pois, para o portador do HIV, já é algo revelado. Não revelado porque é certo que um soropositivo irá morrer (todos iremos), mas revelado pelo imaginário que surge naquele momento dizendo que a morte existe, pois "vivemos o século da anestesia: para tudo existe um anestésico [...]. O resultado inevitável desse equívoco é que estamos cada vez mais assustados e despreparados para a morte - porque se faz de conta que ela não existe" (grifo do autor) (TREVISAN, 2018, p. 618). Ou seja, pode-se dizer que a pessoa soropositiva não está mais anestesiada, está pronta para viver o que há de viver, implicada numa possibilidade de viver uma vida inteira em poucos anos.

Enquanto a realidade da morte é negada a todo momento para muitos, é justamente o que não ocorre com alguém HIV+. Além disso, o resultado positivo para HIV também significa uma experiência de muita dor. "Quantos pesadelos à noite e durante o dia, quanta insegurança no amor, quanto medo ao ver na pele uma mancha esquisita ou ao ter uma gripe prolongada - tudo vira possibilidade de adoecer" (TREVISAN, 2018, p. 617). Portanto, pensar o vírus como todas ações boas do cotidiano pode ser um sentido; seria mais um vírus, somente mais uma coisa simples da vida como abraçar, beijar e tocar. Porém, não se esquecendo de todo um imaginário, do interdiscurso, em que o diagnóstico dificilmente representará algo bom, faz sentido essa tentativa de a campanha desconstruir um medo tão fossilizado com os seus discursos. É, por assim dizer, o surgimento de uma formação discursiva em que a palavra positivo não significa dor, isolamento, morte, enfim, algo ruim em relação a um diagnóstico positivo no caso do HIV.

Como apontam Haroche, Pêcheux e Henry (2011), "as palavras "mudam de sentido' ao passar de uma formação discursiva a outra.". Levando-se em conta o 
imaginário - aquele em que um diagnóstico positivo aponta para a sentença de morte, a doença e tempo de vida - que surge e ressoa no momento da descoberta da soropositividade, o discurso que denota um outro sentido para a palavra positivo quer rever, além de tudo, os pré-conceitos que se tem sobre o vírus.

Outrossim, em se tratando de observação do corpus, Ernst-Pereira (2009) lançanos como categoria de análise, de princípio geral para o olhar do analista, o conceito de estranhamento. É a "estratégia discursiva que expõe o conflito entre formações discursivas e consiste na apresentação de elementos intradiscursivos [...] e interdiscursivos, da ordem do ex-cêntrico, isto é, daquilo que se situa fora do que está sendo dito." (ERNST-PEREIRA, 2009, p. 5). Mesmo se situando fora, o que acontece sem antes associá-lo a mais discursos, continua trazendo algum significado. Assim, o sinal de mais em vermelho na palavra positivo no discurso da campanha e que causou, num primeiro momento, um estranhamento, se apresenta como uma materialidade externa, mas que quando o remetemos a um interdiscurso sobre HIV, é possível "colocálo" em uma cadeia significante.

Seguindo com as análises, a palavra positivo sempre aparece diferente. Aparece não só como está escrita nas SDs, mas também como descrito no parágrafo anterior, enfim, ao observarmos a imagem 1, podemos ver que a letra $\mathrm{T}$ da palavra está trocada por um sinal de positivo em cor de vermelho. Além do que já foi discutido sobre a palavra, cabe, neste momento, pensar em sentidos para o sinal, a cor, as duas coisas juntas e a palavra.

Visto que, como nos diz Pêcheux (2015b, p. 158), "é porque os elementos da sequência textual, funcionando em uma formação discursiva dada, podem ser importados (meta-forizados) de uma sequência pertencente a uma outra formação discursiva que as referências discursivas podem se construir e se deslocar historicamente.". Isto é, pelo discurso se apresentar numa emaranhada rede de discursos, consequentemente, os sentidos estarem sempre ligados a outros, que analisar os elementos separados e juntos se faz importante para compreendermos as condições de produção do discurso.

O símbolo de positivo na matemática é definido pelo sinal de mais (+), sinal é a palavra para designar os símbolos utilizados na linguagem matemática. Portanto, os sinais de mais e menos são utilizados não somente para representar positivo e negativo, como também representam adição e subtração. $\mathrm{O}$ sinal de mais pode, então, ser definido como um operador que indica adição (adiciona mais algum valor ao que já se tem), um operador unário (o sinal até mesmo nem precisa ser utilizado, como em +1 , que é igual a 1 , diferentemente de -1 , em que o sinal de menos deve estar expressado), e pode significar, também outras operações, mas que aqui não se fazem necessárias.

Muito comum na área da saúde, o sinal de mais vermelho é o símbolo da Cruz Vermelha, uma organização humanitária que tem como objetivo proteger a saúde e a vida humana, promovendo o respeito entre as pessoas e diminuindo o sofrimento, tendo sido surgida no século 19 pensada pelo suíço Dunant, que em um pós guerra publicara um livro com seus pensamentos voltados à criação de práticas humanitárias, como a formação de sociedades voluntárias para ajudar e proteger feridos de guerra. 
Outrossim, a cor vermelha é a cor do sangue e do fogo, por isso associa-se a cor à energia e vida. Como possui alta visibilidade, o vermelho está bastante presente em nosso cotidiano: em semáforos (indicação de pare), botões e ferramentas de emergência (o hidrante, a alavanca nas janelas de ônibus), em sinais de advertência ou perigo, e, em livros didáticos de matemática, por exemplo, quando a solução de uma operação está errada, essa se apresenta em vermelho (sendo em azul para correto). E, lembrando, se o saldo de alguém é vermelho, como nos diz a expressão idiomática do português brasileiro, "a pessoa está no negativo", ou seja, sem crédito. Também, determinado como o mês de luta contra a AIDS e conscientização, o mês de dezembro é intitulado como Dezembro vermelho.

Tendo em vista que são as condições de produção do discurso capazes de determinar algum sentido para o mesmo, mas que também todas essas relações interdiscursivas contribuem para o sentido sempre poder ser outro (mas não qualquer um), pensemos o que todas essas ambiguidades podem significar no enunciado da campanha.

Sabendo que justamente a letra $\mathrm{T}$ foi trocada pelo sinal de mais, podendo não só indicar que o positivo da sorologia está dentro do que é positivo (no cotidiano, na vida), pois se tem ali, da matemática, uma adição, mais um valor. Também compreendendo que a cor do sinal pode ser associada com o sangue, paremos para pensar o que é o sinal/a letra na nossa corrente sanguínea: o positivo, o sinal de mais, é também a letra T, que em se tratando de HIV, sabe-se que o vírus quando detectável no organismo, ataca, como principal alvo, as células de defesa chamadas de linfócitos T-CD4+.

Desse modo, podemos perceber toda uma rede de discursos que o sinal evoca, é possível pensar o sinal, o sinal com a palavra, o sinal com a cor e todos juntos, provando, mais uma vez, que no intradiscurso temos dizeres que podem ser inscritos em diversas formações discursivas do interdiscurso. Na campanha, no caso, como a palavra posi+ivo se materializa no cartaz, é concebível refletir sobre os diferentes efeitos de sentido que se apresentam.

$\mathrm{Na}$ SD7, temos a palavra negativo qualificando o ato de discriminar. Com todas as ações positivas do cotidiano, definitivamente, uma negativa é o que vem da discriminação, das violações. Na imagem 1 pode-se observar que "HIV+" está na cor vermelha, o que automaticamente chama a nossa atenção, ao lado, em seguida, vem o dizer "negativo é discriminar". Interessante o fato, se "chamarmos" por um imaginário o qual o sujeito lê a palavra HIV+ e considera somente o que há de negativo, como discutido anteriormente, a função que "negativo" exerce logo em seguida é a de barrar esse pensamento e imaginário e impor que a única coisa de ruim, negativa, que há ali é a discriminação. Ainda, dito de outro modo, discriminar é mais negativo do que o resultado da soropositividade, mesmo que "HIV+" escrito em vermelho pode significar uma resposta negativa (errada) como nas operações matemáticas e que, neste caso, contribui para a criação do imaginário sobre o vírus e a doença.

Por fim, na SD8, o discurso nos sugere um jogo de ambiguidades em que a afirmação da conclusiva pode ser assim parafraseada: No final, as 9 não são HIV+, uma delas é; No final, nada mudou, as 9 continuam não sendo HIV+. Para tanto, pensando nessas paráfrases, utilizamos do conceito de enunciado dividido formulado por Courtine (2009), o qual aponta para o modo como em uma mesma materialidade linguística podem 
estar existindo enunciados que pertencem a formações discursivas divergentes. Isto é, na materialidade "no final", temos dois enunciados a seguir que divergem entre si em relação à posição-sujeito que estão inscritos, desse modo, podendo apontar para uma diferente formação discursiva.

No vídeo da campanha, quando aparece a SD8, estão grifadas as palavras "nada mudou, uma delas". Dessa forma, questionando-se sobre o sujeito gramatical para a palavra "mudou", podemos pensar o seguinte enunciado dividido:

$$
\text { E = No final, } \frac{\text { e } 1 \rightarrow \text { nada mudou. }}{\text { e } 2 \rightarrow \text { uma delas é HIV+. }}
$$

Nada mudou em relação a todas as ações realizadas e a transmissão do HIV. Houve, nesse caso, o abraço, o beijo etc.; e nas 9 pessoas soronegativas, a sorologia não mudou. Nada mudou também com a pessoa soropositiva, após os diversos tipos de contatos, essa continuou vivendo com o HIV, portanto, no final, nada mudou as/nas pessoas. Esse nada se refere à sorologia, pois tem-se nas condições de produção desse discurso um experimento em que o objetivo é mostrar que os contatos apresentados não são fatores vulneráveis de transmissão do vírus, logo, conclui-se que o sujeito gramatical enquanto referido a soropositivos, esses continuaram soropositivos e se fosse soronegativos, também continuaram soronegativos (não testando positivo para o HIV).

$\mathrm{O}$ e2 remete ao campo em que saber a soropositividade de alguém importa, sendo inscrito em uma posição-sujeito que, dentro de uma FD da discriminação, discriminar/distinguir a diferença se faz necessário. Já no e1, quando se utiliza de nada, não há distinções sendo feitas, podendo assim dizer que essa posição-sujeito não se identifica dessa FD da discriminação para ocupar uma posição em outra FD mais especificamente não discriminatória, na qual as diferenças não importam e os discursos de equidade se fazem presentes.

\section{CONSIDERAÇÕES (PARA O AGORA E UM FUTURO)}

O histórico do HIV e AIDS em nossa sociedade nos mostra ainda o quão necessárias são as lutas não só pelo entendimento da população com a importância da proteção e tratamento, mas também pela compreensão de que quem vive com o HIV, vive uma vida como as outras e de quem convive, que pode fazer muito pelo outro trazendo informação e lutando contra um sentido mórbido em relação a essas letras.

Diversos são os discursos, no campo da saúde, científico, social que instauram um imaginário estigmatizante e preconceituoso contra o vírus, a doença e a pessoa soropositiva. Desse modo, entende-se que o vírus é nosso, ou seja, não é só dos homossexuais, dos pobres ou a minoria que seja, o vírus pode ser transmitido a qualquer um independente de raça, sexo e classe social. Por isso se luta por esse fim da estigmatização. Tratar o vírus sem discriminação não é um incentivo a novos contágios e a desistência de encontrar uma cura. Tratar o vírus sem discriminação se refere a tratar as 
pessoas que vivem e convivem com HIV e AIDS com igualdade, com respeito e cuidado afetivo e também estar do lado desses na luta contra o vírus e a doença.

As campanhas, nesse sentido, surgem sempre por parte dos responsáveis pela saúde e do bem-estar social. ONGs, secretarias e ministérios da saúde trazem discursos endereçados a pensar o outro, ajudam no reconhecimento e respeito com a diversidade do povo que vive e convive com alguma condição de saúde. Sendo que, até mesmo dentro de consultórios e postos de atendimento pode-se sofrer alguma discriminação por parte de profissionais da saúde por conta de um teste, um resultado, uma busca por informação. Assim, além de conscientizar uma população para o cuidado e respeito, é necessário também um trabalho com os profissionais responsáveis em nos oferecer o serviço de saúde.

A Análise do Discurso se apresenta também como uma ferramenta capaz de identificar os processos de produção de enunciados, além disso, chama a atenção para os sentidos possíveis de serem eleitos no discurso. Ou seja, pensando as materialidades linguísticas do discurso, seja o texto oral ou escrito, e que essas são interpeladas pela ideologia, é concebível que entendamos as formações discursivas nas quais os discursos se inscrevem.

Nesse sentido, como foi discorrido neste trabalho, é possível pensarmos em duas formações discursivas opostas em relação aos discursos sobre HIV e AIDS: uma em que busca a equidade, informação e respeito (zero discriminação) e outra que estigmatiza e surge com um imaginário de terror, de medo do vírus e da doença, medo da morte e aponta para soropositivos como não merecedores de contato humano, de vida e ações simples do dia a dia.

Os emaranhados de fios de discursos na nossa sociedade, em nosso imaginário, não só em palavras, como em cores, sinais, possibilitam um traçar de sentidos e a construção de, por exemplo, uma campanha de saúde que busca demonstrar que viver com o HIV não é tão negativo quanto se pensa. Ainda, mais importante, conviver com o HIV (a pessoa soronegativa que convive com alguém que vive com o vírus - soropositivo) é uma atividade plenamente possível e sem riscos, é uma posi+ividade poder abraçar, conversar, compartilhar, gostar, beijar, amar. Então, que tenhamos o desejo de sermos mais positivos, de construirmos uma sociedade com menos preconceito e discriminação zero.

\section{REFERÊNCIAS}

BRASIL. Tratamento para o HIV. Ministério da Saúde. Disponível em: http://www.aids.gov.br/pt-br/publico-geral/o-que-e-hiv/tratamento-para-o-hiv.

BRASIL. Aids no Brasil. Ministério da Saúde, 2010. Disponível em: http://www.aids.gov.br/pt-br/publico-geral/o-que-e-hiv/tratamento-para-o-hiv.

COURTINE, Jean-Jacques. Análise do Discurso político: o discurso comunista endereçado aos cristãos. São Carlos: EdUFSCar, 2009.

ERNST-PEREIRA, Aracy. A falta, o excesso e o estranhamento na constituição/interpretação do corpus discursivo. In: Seminário de Estudos em Análise 
do Discurso, 4., 2009, Porto Alegre, RS. Anais do IV SEAD - Seminário de Estudos em Análise do Discurso. Porto Alegre: UFRGS, 2009.

HAROCHE, Claudine; PÊCHEUX, Michel; HENRY, Paul. A semântica e o corte saussuriano: língua, linguagem, discurso. In: BARONAS, Roberto L. (org.) Análise do discurso: apontamentos para uma história da noção-conceito de formação discursiva. 2.ed. São Carlos: Pedro \&amp; João, 2011 [1971].

INDURSKY, Freda. Formação discursiva: ela ainda merece que lutemos por ela?. IN: Análise do discurso no Brasil: mapeando conceitos, confrontando limites. FERREIRA, Maria Cristina. INDURSKY, Freda (orgs.). São Carlos: Claraluz, 2007.

INDURSKY, Freda. O texto nos estudos da linguagem: especificidades e limites. IN: Suzy Lagazzi-Rodrigues e Eni P. Orlandi (orgs.). Introdução às ciências da linguagem: Discurso e textualidade. 2 edição: Campinas, SP: Pontes, 2010.

ORLANDI, Eni P. Análise do discurso: princípios e procedimentos. 12 ed. Editora: Pontes, Campinas, SP. 2015.

PÊCHEUX, M. As massas populares são um objeto inanimado? In: ORLANDI, Eni. Análise de discurso: Michel Pêcheux. Textos selecionados por Eni Puccinelli Orlandi. Campinas, Pontes, 2015a. Título original: Les masses populaires sont-elles un objet animé?, 1977.

PÊCHEUX, Michel. Metáfora e interdiscurso. Tradução de Eni P. Orlandi. In: ORLANDI, Eni P. Análise de discurso: Michel Pêcheux. Textos selecionados por Eni P. Orlandi. 4. ed. Campinas, SP: Pontes, 2015b.

PÊCHEUX, Michel. Papel da memória. IN: Papel da memória. Pierre Achard... [et al.] 2 edição. Campinas, SP:Pontes, 2007.

PÊCHEUX, Michel. Semântica e discurso: uma crítica à afirmação do óbvio.Tradução de Eni P. Orlandi. 5. ed. Campinas, SP: Editora da UNICAMP, 2014a [1988].

PÊCHEUX, M.; FUCHS, C. A propósito da análise automática do discurso: atualizações e perspectivas. In: GADET, F.; HAK; T. (Org.). Por uma análise automática do discurso: uma introdução à obra de Michel Pêcheux. 5. ed. Campinas, SP: Editora da UNICAMP, 2014b [1975].

RIO GRANDE DO SUL. Zero discriminação. Observatório de HIV/AIDS. Disponível em: http://observatorioaids.saude.rs.gov.br/?page_id=739.

SUPERINTERESSANTE. Como surgiu a AIDS?. 2018. Disponível em: https://super.abril.com.br/mundo-estranho/como-surgiu-a-aids/.

TREVISAN, J. S. Devassos no paraíso. 4. ed. Rio de Janeiro: Objetiva, 2018.

UNAIDS. Estatísticas. 2018. Disponível em: https://unaids.org.br/estatisticas/.

Artigo recebido em: abr. de 2020.

Aprovado e revisado em: jun. de 2020.

Publicado em: julho de 2020.

Para citar este texto:

PIRES, Ezequiel Nunes. Positivo/Negativo: dos efeitos de sentido e imaginário sobre HIV na campanha Discriminação Zero. Entremeios [Revista de Estudos do Discurso, ISSN 2179-3514, on-line, www.entremeios.inf.br], Seção Estudos, Programa de Pós-Graduação em Ciências da Linguagem (PPGCL), Universidade do Vale do Sapucaí (UNIVÁS), Pouso Alegre (MG), vol. 21, p. 243-256, jan. - jun. 2020.

DOI: http://dx.doi.org/10.20337/ISSN2179-3514revistaENTREMEIOSvol21pagina243a256 